\title{
Microbe/Bug-Busters Visit the Interactive House: An Itinerant Scenographic Device for Health Education
}

\author{
Ana Márcia Suarez-Fontes ${ }^{1}$, Juliana Almeida-Silva ${ }^{1}$, Sarah Cristina dos Santos Silva ${ }^{1}$, \\ Letícia Sant'Anna de Souza ${ }^{1}$, Daniele Brum de Souza ${ }^{1}$, Conceição Suarez Fontes de Araújo Lima ${ }^{1}$, \\ Marcos André Vannier-Santos ${ }^{{ }^{*}}$
}

Laboratório de Inovações em Terapia, Ensino e Bioprodutos (LITEB), Instituto Oswaldo Cruz (IOC) —Fundação Oswaldo Cruz

(Fiocruz), Rio de Janeiro, Brazil

Email: *marcos.vannier@ioc.fiocruz.br

How to cite this paper: Suarez-Fontes, A.M., Almeida-Silva, J., dos Santos Silva, S.C., de Souza, L.S.A., de Souza, D.B., de Araújo Lima, C.S.F. and Vannier-Santos, M.A. (2021) Microbe/Bug-Busters Visit the Interactive House: An Itinerant Scenographic Device for Health Education. Open Journal of Animai Sciences, 11, 333-353.

https://doi.org/10.4236/ojas.2021.112024

Received: February 7, 2021

Accepted: April 27, 2021

Published: April 30, 2021

Copyright $(2021$ by author(s) and Scientific Research Publishing Inc. This work is licensed under the Creative Commons Attribution International License (CC BY 4.0).

http://creativecommons.org/licenses/by/4.0/

cc) (i) Open Access

\begin{abstract}
The term Ecology is derived from oĩ our habitations usually overlooked in ecology or environmental studies. The expression "at home" usually means safety and comfort, but at home we are under risk of innumerous parasitic/microbial infections and contaminations/ envenomation. During the COVID-19 pandemic we were forced to stay at home, but the virus and other pathogens were also home-delivered. Education for health is highly effective in health promotion, particularly in poor areas. Thus, prophylactic interventions approaching household environment are required. The present activity aims community empowerment and engagement in controlling parasitic diseases and other infections such as Chagas disease, leishmaniasis, malaria, arboviruses etc. Inspired on the use of a house maket by Dr. Virgínia Schall to demonstrate Aedes mosquitoes breeding sites. We also employ house makets displaying pathogen vectors breeding/hiding sites. Although some makets can be opened, revealing intradomiciliary milieu, we intended to offer the public a literally "insider" view of this largely overlooked scenery. The "Interactive House", also known as "House with no viruses and other bugs" is an educative, interactive, ludic device elaborated on an inflatable igloo, with furniture and utensils crafted using reused/recycled or low-cost materials. Live mosquito larvae were placed at peridomicile in water-accumulating plant pot saucer, leaves-clogged gutter, used tire, dog water bowl as well as within the domicile, in the shower drain trap. Evidengue ${ }^{\circledast}$, crafted in cloth to block mosquito oviposition developed is presented. Participants enjoy taking part in the activity, seem amused, play, laugh and smile while enthusiastically take pictures. This educative activity
\end{abstract}


permits health communication in a ludic interactive way, which may contribute to health promotion in areas with public health problems.

\section{Keywords}

Science Communication, Health Education, One Health, Environmental Health, Parasitic Diseases

\section{Introduction}

Innumerous communicable diseases pose a heavy burden of morbidity and mortality worldwide, particularly in tropical regions further contribute to poor public health conditions and so hampering socioeconomic development [1].

The word Ecology is derived from the Greek word oĩkoc, for "house" (environment), but our residences usually do not reside under the same roof with the concepts of ecology or environment, and households are rarely approached in ecology textbooks. The term "environment" comes from the French word "Environ" (environner - en + viron: at turning; walking around; Anglo-French: enviruner), indicating the area around our households but despite the use of the word milieu is often used to designate environment, it scarcely ever includes our homes.

For most people to be "at home" means safety and comfort, but one's housing may comprise risk factor for climate changes [2], pollution [3] [4], tobacco smoke [5], asthma [6] cardiac conditions [7], lead poisoning [8], envenomation [9] [10] and infections [11]. During the SARS/CoV-2 pandemic, many of us decided to stay safe at home, but the virus [12], as well as other pathogens as both parasitic and diseases [13] and microbial infections, are transmitted in the domiciliary and peridomiciliary milieu. Anthropogenic actions often generate conditions to promote the infection spread.

Different infectious are transmitted with the participation of reservoir hosts and/or invertebrate vectors. American trypanosomiasis or Chagas disease is caused by Trypanosoma cruzi and transmitted to man among other mammalians by Reduviid triatomines, which are frequently detected in the domiciliary and peridomiciliary environments [14] [15] [16] [17] [18]. Likewise, Leishmania spp. the causative agents of leishmaniases are vehiculated by phlebotomine sand flies bloodmeals [19], which often occur in the domiciliary-peridomiciliary setting [20] [21] [22] [23]. In both Chagas disease and leishmaniasis dogs (Canis lupus familiaris) have been implicated in the disease transmission, as this mammal comprises frequent reservoir hosts for T. cruzi [24] as well as for Leishmania sp. and canine kennels are often colonized by phlebotomines [25] and triatomines [26]. Thus, the presence of domestic dogs in the peridomicile comprises a risk factor in the transmission. Several other mammalian species including cats [27] and equids [28] can act as primary and/or secondary synanthropic reservoir 
hosts in the Leishmania spp. transmission, besides many wild animals such as rodents, marsupials, etc. [29]. Similarly, Trypanosoma cruzi infects domestic cats (Felis catus) [30] as well as over 100 mammalians including domestic, peridomestic, and wildlife reservoir species, potentially involved in Chagas disease ecoepidemiology [31].

Environmental use conditions may deeply influence the vector populations, thus affecting the dynamics of these protozoal diseases with trypanosomatid etiological agents [32]. As vector such as triatomines in anthropogenically altered environments tends to feed on short-lived, highly susceptible animals with high reproduction rates, such as rodents [32], which may suffer population bottlenecks as reported for guinea pigs [33], the infection rates in peridomiciles are often significantly superior as the ones observed in the wild [34], as reported for triatomines [35].

The availability of nutrients/organic material in the peridomicile may promote the colonization and/or proliferation of vectors and reservoir hosts in this microenvironment. As peridomiciliary organization and cleanness may reduce the amount of captured sand flies [36] its cleaning and organization was shown to diminish phlebotomine numbers by circa $90 \%$ [37], so may be used as a leishmaniasis control measure. Similarly, improved housing may be instrumental in the prevention of Chagas disease [38]. In addition, dirty flooring and inadequate trash deposition in intradomiciliary and peridomiciliary sites promote colonization by triatomines [39] [40] [41]. The endeavour reported here was conceived to empower the public about prophylactic measures in a ludic interactive manner. The "Interactive House", also known as "House with no viruses and other bugs" is an educative health promotion tool comprised by a scenographic house, handcrafted in low-cost material, in which disease vectors, mice and poisonous animals (rubber made) can be hunted by children, health professionals (e.g. Community Health Agents) and lay people. Prophylactic procedures are discussed in a ludic and dynamic way to help prevent infections and envenomation within the peridomiciliary and intradomiciliary environment. Similarly, the contact with the arthropod vector among 90\% of Chikungunya Mexican patients were reported to take place in the peridomiciliary environment [42]. Also, Dengue and Zika fevers, both transmitted by Aedes aegypti or A. albopictus mosquitoes are frequently acquired in the intra-domiciliary and peridomiciliary areas [43].

The household insertion in the environment and epidemiological chain of disease spread is required for the comprehensive one-health view [44] [45] integrating animal and human health with the environment, may be instrumental in surveillance and controlling diseases such as leishmaniasis [46], Chagas disease [47], malaria [48] and predicting zoonotic arthropod-borne disease outbreaks [49] [50] as improved environmental housing and peridomiciliary conditions may be useful for and vector/reservoir control. Therefore, it is important to understand the housing threats in order to avoid them. Thus, the present educational activity was devised for health promotion particularly focusing on ne- 
glected diseases.

\section{Materials and Methods}

The "Interactive House", also known as "House with no viruses and other bugs" was designed and elaborated in an inflatable igloo, approximately $6 \mathrm{~m}$ high and 8 $\mathrm{m}$ in diameter (Figure 1). Replicas of furniture and small appliances crafted employing reused or low-cost materials such as Styrofoam, tradeshow boxes, cardboard boxes, pallets, PET bottles, CDs, are organized inside. The rooms were separated by cardboard dividers, in which each side depicted a different environment, assembled to maintain a flow of information, starting the guided visit in the living room and ending in the outside peridomiciliary area.

The choice of items for the composition was based on houses in the suburbs of Rio de Janeiro (not too different from most residences in low income areas of

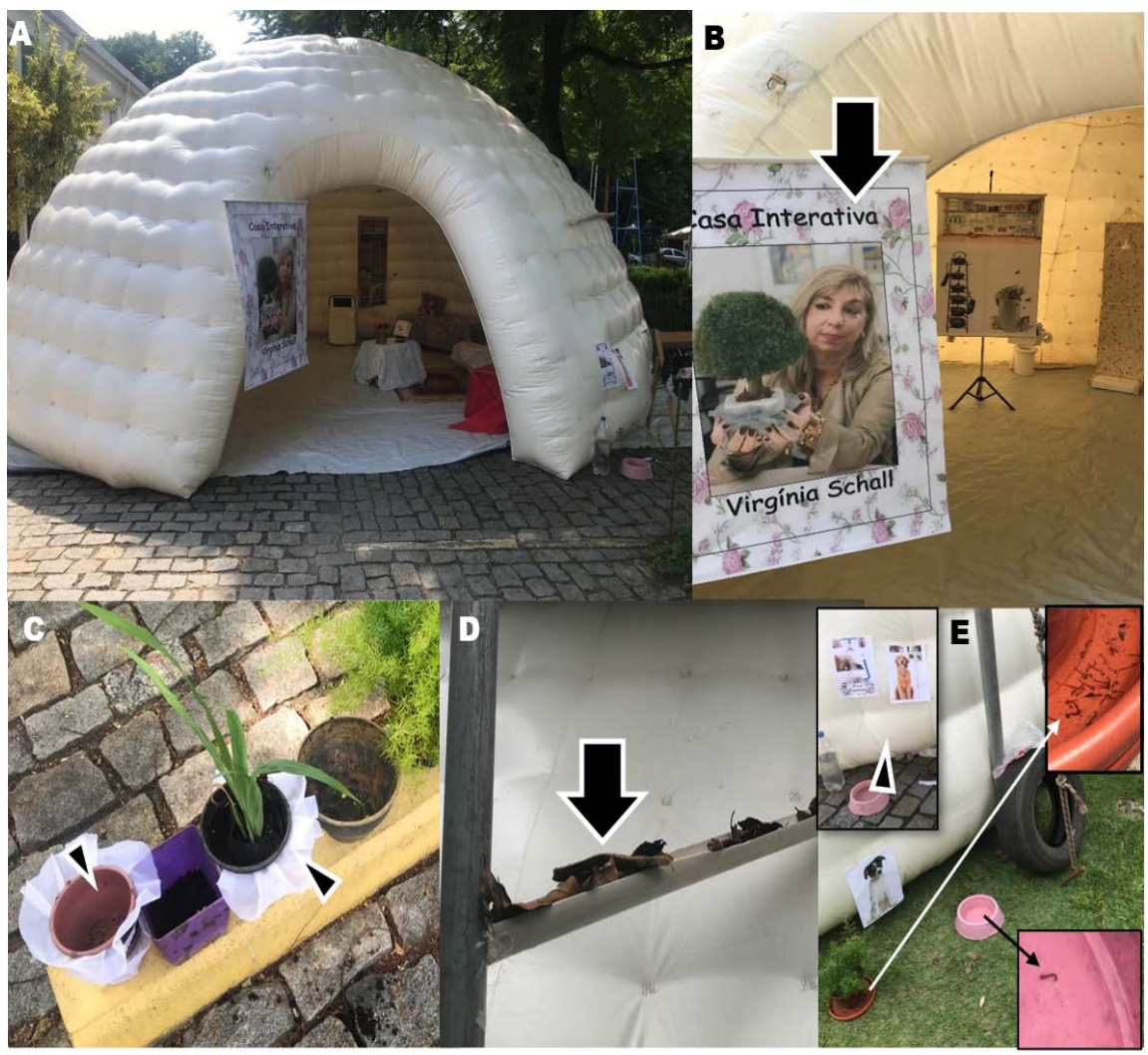

Figure 1. Educative, interactive, ludic implement named "Interactive House" ("House with no viruses and other bugs"), honoring Virgínia T. Schall (in memoriam), mounted on an inflatable igloo, devised for demonstration breeding sites and hiding spots of vectors such as Aedes aegypti and triatomids, as well as house colonization by other animals harmful to health. House entrance (A), (B) with a banner depicting the researcher Virgínia Schall showing Evidengue ((B), arrow), a device crafted in cloth to block mosquito oviposition on the water-accumulating saucer ((C), arrowheads). A leaves-clogged gutter showing water accumulation ((D), arrow). Peridomicile (E) presenting plant pot with saucer displaying water with living larvae (white arrow-top right inset), used tire near dog bowl with water (and eventually larvae, black arrow-bottom inset), with images showing dogs and the Leishmania life cycle (top left inset, arrowhead). 
Latin America as well as many parts of the developing world), i.e. a room displaying a sofa (pallet, cardboard boxes, paper and TNT cloth), coffee table (cardboard and PET bottles as table legs), rubble (broken bricks and tiles, shards, crates), pillows and carpet for decoration; bedroom showing a bed (two juxtaposed wooden crates, 2 children's bedsteads, children's mattress, sheets, pillows and a cloth made doll), carpet and corresponding partition containing a small closet (cardboard box, paper, popsicle sticks, wire and TNT; bathroom: a toilet (plastic trash can, toilet seat, felt-covered Styrofoam), shower stall (Styrofoam, cardboard, adhesive paper, unused shower and drain), rugs and 2 matching partitions containing a sink (cardboard box, adhesive paper, faucet) a mirror (used CDs and adhesive paper), small shelf (cardboard and paper) with decorative items made of straw, EVA sheets, twine, cardboard and food packaging, as well as a trash can (PET bottle); Kitchen: cabinet (cardboard boxes, paper, EVA), sink (cardboard boxes, Styrofoam, sticky paper, popsicle stick, aluminum foil, PVC, TNT and tap), stove (cardboard box, grey contact paper, miscellaneous bottle caps, CDs and EVA), refrigerator (cardboard boxes, EVA and contact paper), mats and corresponding partition containing a small shelf (cardboard, brown paper), as well as decorative items such as a small empty gas canister, cookware (EVA), condiments (acrylic and cardboard cups), packaging (empty medicine boxes and paper), blender (Styrofoam box, various bottle caps, plastic cups and cardboard), among others (Figure 2). Within this milieu, specimens of triatomine of the genus Rhodnius were inserted in places where the disease vectors are often found in the home environment, such as under the bed, behind frames and furniture, among others.

Besides addressing Chagas disease and vector shelter sites, the House also presents information about Aedes aegypti-transmitted arboviruses, with breeding sites in the toilet, and potted plants. In the latter, we pay tribute to the researcher Virgínia Schall, who devised Evidengue ${ }^{\circledast}$, a cloth-made device to cover plant pot saucer, an easily crafted tool to prevent the proliferation of mosquitoes in the external or internal area of the residence. The Evidengue ${ }^{\varpi}$ was made using a plastic bag, or a cloth, and tied with a ribbon or string, completely wrapping the pot and saucer, so that mosquitoes cannot reach accumulated water [51]. The visitation to "Interactive House" ends at the external environment where a used tire is identified presenting living mosquito larvae (previously introduced) which can be easily collected and observed using clear disposable glasses, a drain chute blocked with leaves, a dog bowl, an Evidengue ${ }^{\circledast}$, presented in a simple way, discussing alternatives to combat vectors and reservoir hosts breeding in the household environment. Rubber-made poisonous animals such as scorpions and centipedes (Class Chilopoda) were added as well as rats and cockroaches, in order to raise discussions on envenomation and infections spread, promoted by inappropriate trash deposition. Breeding sites for sand flies and anopheline mosquitoes are also presented and discussed, particularly in the malaria and leishmaniasis endemic areas. 


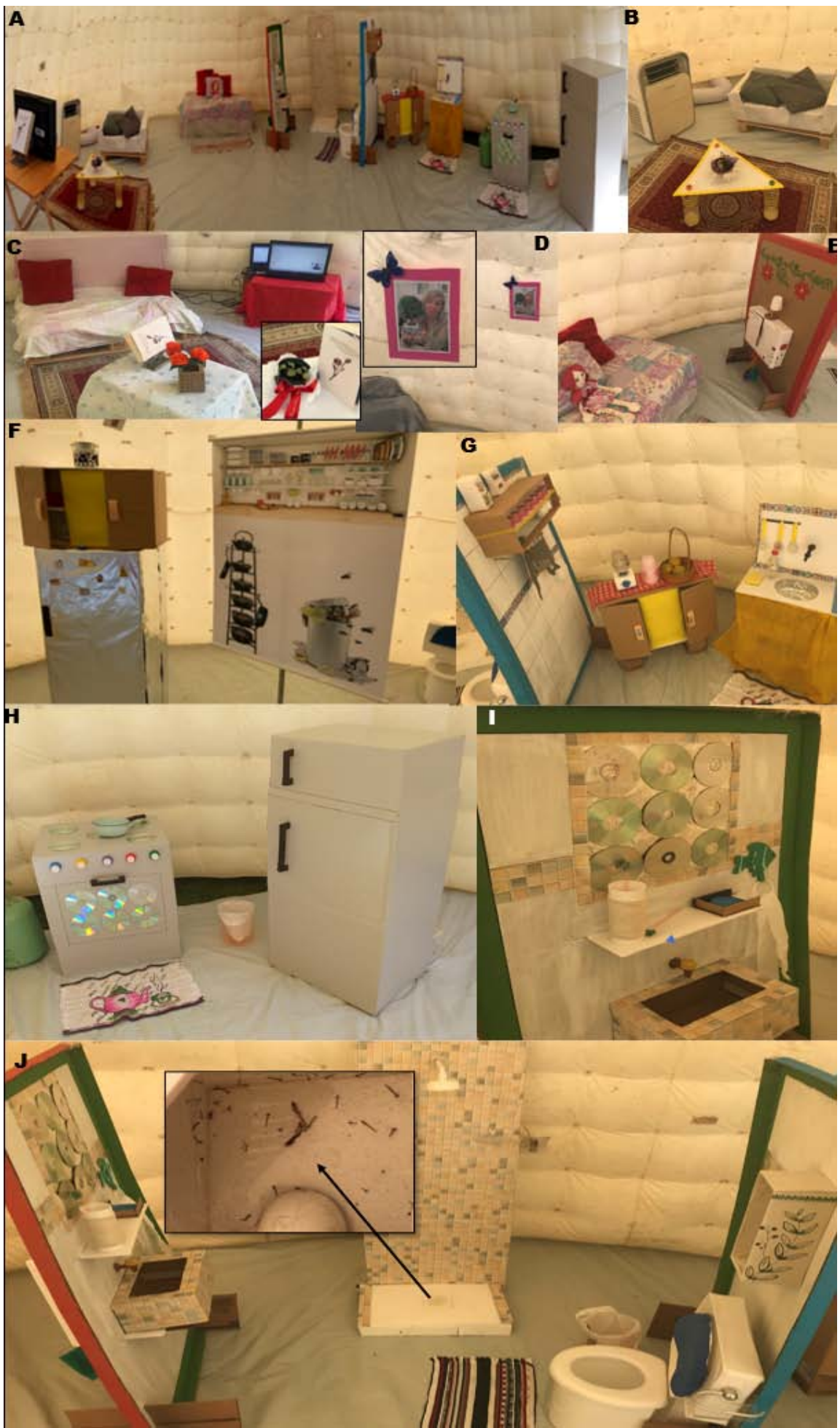

Figure 2. General view of the home setting, displaying most of its pieces of furniture (A). Details of the living room showing small table, sofa, air-conditioning system (B) a table with the TV presenting scientific videos and another with a book approaching the scientific legacy of Virgínia Schall (C), often placed besides an Evidengue ${ }^{\circledast}(\mathrm{C})$, inset), with the Virgínia picture hanging on the wall ((D) inset) and a bedroom (E). House kitchen (F-H) and bathroom $((\mathrm{I})$ and $(\mathrm{J}))$. Within the shower drain trap, living mosquito larvae are placed $((\mathrm{J})$, inset, arrow). 


\section{Results and Discussion}

It could be ironically sad that we are "never home alone" for we have myriads of bugs sharing our residences [52]. Nevertheless, most of our uninvited guests are unpleasant and even dangerous. The cohabitation with unpleasant insects is clearly indicated by the taxonomic designation of the housefly (Musca domestica L.; Domus-house). Interestingly the ubiquitous and cosmopolitan nematode Enterobius vermicularis is so often acquired in the intradomiciliary environment that in parts of Brazil the worm was nicknamed "caseira" from the Portuguese word for "house" ("casa"). Even our invited and beloved guests, such as dogs and cats, help to attract the uninvited nasty ones. As unequivocally shown in the biblical citation EXODUS 8:24 [52] "And there came a grievous swarm of flies into the house of Pharaoh, and into his servants' houses, and into all the land of Egypt: the land was corrupted by reason of the swarm of flies." Flies are very "democratic" and not quite demanding in picking domiciles and this is also true for cockroaches. Thus, the infections they harbor may be wide-reaching, particularly because different arthropods may travel by ships, trains, planes etc.

The present report was titled after an activity named in honor of the notorious Brazilian scientist Virgínia T. Schall in memoriam (not only acknowledging her strategy that sparked the present activity, but also as a modest tribute to this remarkable educator). Her team used to employ a house maket to demonstrate the water accumulation and therefore the potential Aedes sp. breeding sites [53]. "On the shoulders of such a giant"1 we decided to elaborate several makets displaying different parasitic disease agents, and allow the public to enter such house, here termed "Interactive house with no viruses and other bugs", handcrafting the house in an inflatable igloo (Figure 1), but it was also mounted on an ordinary classroom. The use of recycled, reused or low-cost materials (Figure 2) allows the activity adaptation under different conditions in schools found in low-income areas. The hands-on activity of the house elaboration may comprise a ludic/artistic task, gathering teachers on both science/biology and arts, as well as students, parents (craftsmen, seamstresses/couturiers, carpenters and handymen in general are welcome). This is an important creative moment of the process and both graduate and undergraduate students clearly enjoy it.

Plastic/rubber or resin incrusted arthropods and other dangerous or noxious animals were acquired or prepared (Figures $3(\mathrm{~A})-(\mathrm{H})$ ). Combined display, such as ants feeding on a dead roach as well as infest food (Figure 3(I), Figure 3(J)) are exhibited to illustrate the foodborne insect-mediated dissemination of different microbes. Similarly, ant/fly toys on top of stools, as well as on food (Figure 3(K), Figure 3(L)), were employed to emphasize the insect role in mechanical spreading of pathogens. Eventually a team member asks: "Is it true that eating ants is good for eyes?" After discussing this legacy of tribal healers from India, still a poplar saying in Brazil, the visitors understand that ants [54] and roaches may be similarly contaminated, often carrying the same microbial species

\footnotetext{
${ }^{1} \ldots$ as well as on the ones of Sir Isaac Newton!
} 


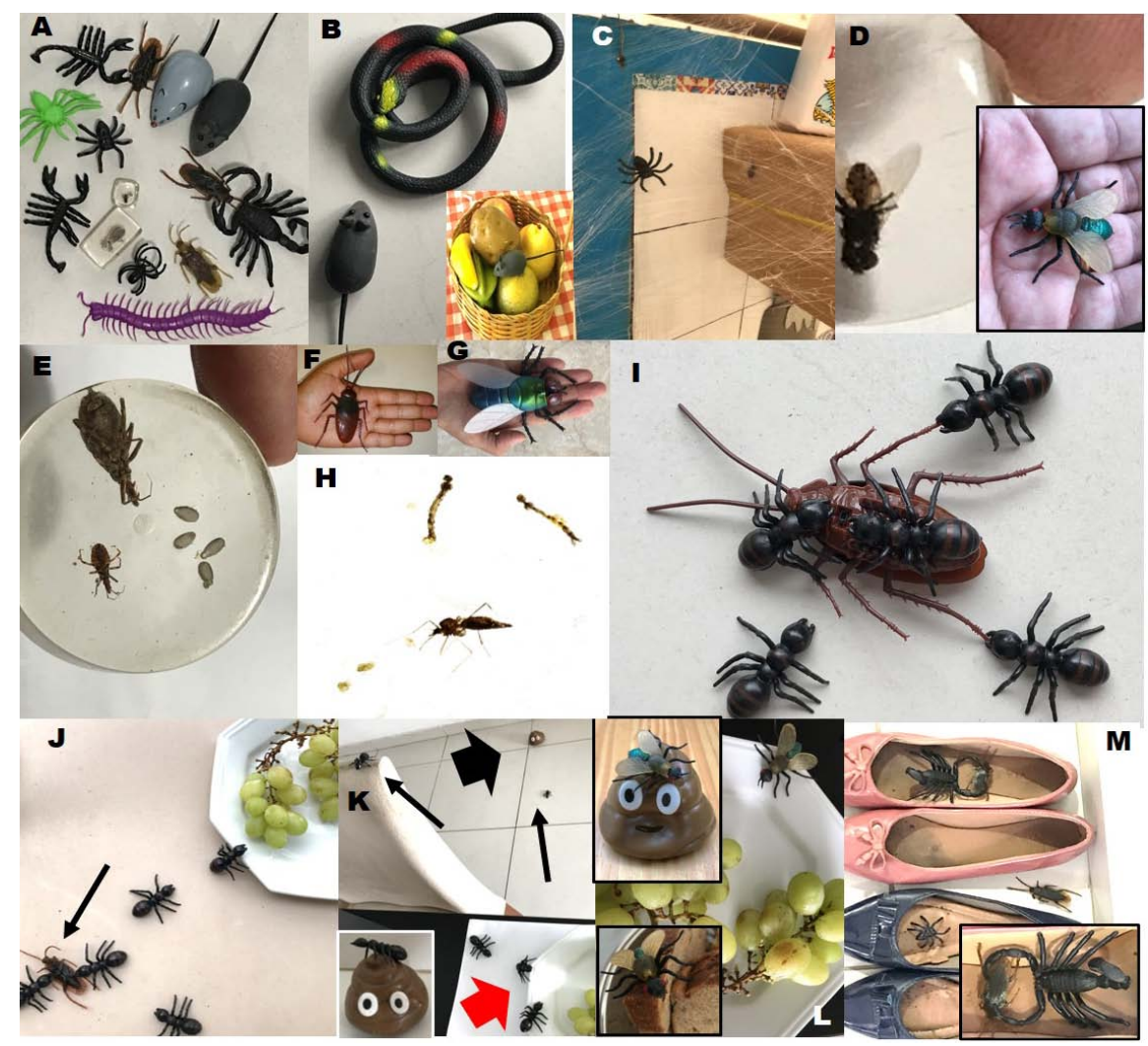

Figure 3. Rubber-made cockroaches, centipedes, spiders, scorpions etc. (A) are used in the activity. As mice and rats are often preyed by snakes a rubber snake is place near a toy mouse in some areas (B); Rubber mice are placed in trash or fruit bowl (inset). Rubber spiders are placed on glue-made webs (C). Transparent resin-incrusted (D), plastic flies (D, inset), incrusted kissing bugs $(\mathrm{E})$ and mosquitoes $(\mathrm{H})$ are presented during the visits. Lange battery powered cockroach (F) and fly $(\mathrm{G})$ are also employed in brief theatre sketches during the visit. Rubber-made ants are shown feeding on roaches (I), as well as on our food (J arrow-rubber cockroach). Sometimes toy assemblages are arrayed to display plastic ants $(\mathrm{K})$ and house flies (L) on top of gel-made dog stools (upper inset) as well as on food dishes with fruits or bread (lower inset). Rubber arthropods placed within shoes $(\mathrm{M})$, where scorpions are represented preying on roaches (inset).

[55]. The team tutors ask: "Would anyone here discard a delicious fruit juice in the tropical summer after detecting a poor, little, drowning ant?" Usually the unanimous answer is "no". The answer is quite different when we consider a swimming cockroach. At the end we ask them: "Ok, you can save the ant, but can you save yourself from its microbes?"

Distinct arthropods function as microbe mechanical vectors. Cockroaches (Blattidae) [56] [57] and non-hematophagous flies such as houseflies were shown to spread numerous human pathogens, including bacteria, parasites, fungi and viruses [58]. In addition, different arthropod species [59] [60] [61] [62] [63], can disseminate of antimicrobial resistance. It is noteworthy that ants (Formicidae), although not so repulsive ${ }^{2}$ as roaches, are also involved in the dissemination of bacteria [54] [64] [65] [66], including drug-resistant strains [59] [67] [68], and

${ }^{2}$ Exactly for being less repulsive, ants are presumably less fought, so comprise an insidious health risk. 
fungi [69].

Similarly, toy mice placed on wax fruits (Figure 3(B)) also stimulate discussion on infections such as leptospirosis and peridomiciliary transmission of Leptospira related to inadequate environmental conditions [70]. Besides, snakes prey on rats and mice therefore, dirty yards and wasteland with intense rodent proliferation maybe attractive for the predators including poisonous snakes. In this line of thought, the display of scorpions holding cockroaches is to remind their predator-prey relationship, therefore dirty places may be suitable for cockroach infestation and thus, attractive for scorpions. In this regard, scorpionism is a public health in many parts of the world [71] and the significantly increased number of cases and deaths in Brazil [72], indicating the animals are adapting to urban/peridomestic conditions [73]. Thus, scorpion control program was proposed, including cleaning and education [74].

The public enjoyed taking part of the activity and interacted with the scenographic environment (Figures 4(A)-(C)), Different rubber-made arthropods such as roaches, ants, flies, centipedes and scorpions are placed at concealed dark spaces/hidden spots (Figure 4(D), Figure 4(E)) such under furniture, within shoes and by scrubs as well on the trash.

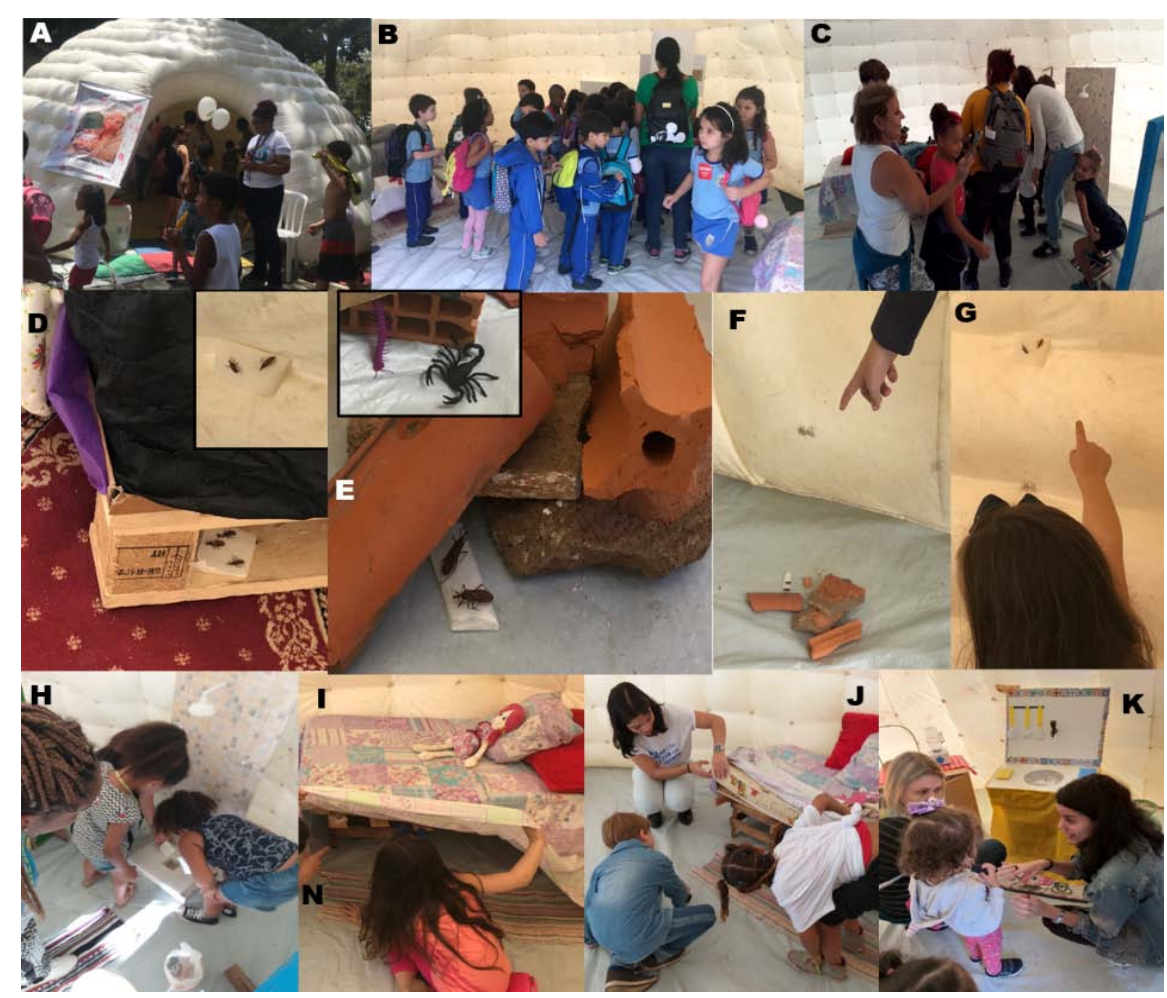

Figure 4. The interactive house is generally attractive, gathering many kids in schools and science fairs (A), (B) and they enjoy playing and taking pictures within it (C). Dead triatomines are tape-fixed under the bed or sofa (D) fixed on the walls ((D), inset) and by scrubs (E), (F), associated to centipedes, scorpions etc. Visitors are invited/challenged to search for and identify the bugs inside and outside the house, on the scrubs (F) walls (G), within the shower drain trap $(\mathrm{H})$ under the furniture (I), (J) always aided by the project team $(\mathrm{J}),(\mathrm{K})$. 
The house also displays living mosquitoes' larvae in breeding sites such as shower drain trap, as well as in the peridomicile in water-accumulating plant pot saucer, used tire, dog water bowl. The children, teenagers and even adults show surprise and amusement facial expressions as they discover the rapidly moving larvae. Adult triatomines (fixed on tape or transparent resin-incrusted), are placed in similar places as the other arthropods mentioned above. The use of images permits "insights" on different scientific fields [75] [76]. In the handwashing activity mentioned above, observing the dirt on the hands through a digital microscope [77], creates an emotional experience able to change the behavior of children and teenagers even after over a year and it was declared by teachers and city personnel. In this activity, the visual stimuli of the house, furniture, appliances, bugs and particularly the actively moving mosquito larvae also comprise an easily remembered experience so we expect these visitors to consider the prophylactic measures discussed in the events. The visitors, including health professionals such as health agents, unequivocally enjoy playing the "bug buster" role (Figures $4(\mathrm{~F})-(\mathrm{I})$ ), with the encouraging participation of the team tutors (Figure $4(\mathrm{~J})$, Figure $4(\mathrm{~K})$ ).

The gender frequency of public visiting Interactive House in health promotion events was mostly comprised of female participants (Figure 5(A)) and it maybe interesting since the maternal education level was shown to be inversely related to childhood mortality [78] [79]. The Word Cloud generated on the overall replies of the interviewed participants entering the "Interactive house", displays "walls" and "mattress" as the most frequently used terms indicating the main kissing-bug (triatomines) hiding spots (Figure 5(B)). The analysis of these indications among age groups revealed that most indications are increased with age, except for rubble, more indicated by the younger participants (Figure 6), possibly indicating the proximity caused by the reduced height as well as playing activities particularly in the house yards. In this regard the roof is rarely mentioned among the younger group. This tool may be useful in approaching the knowledge, attitude, and practices (KAP) in endemic area populations.

Peridomestic environmental conditions may be also involved in the transmission of helminths among humans and animals with zoonotic potential [80], Chagas disease [81] and leishmaniasis [82]. Besides T. cruzi and Leishmania spp.

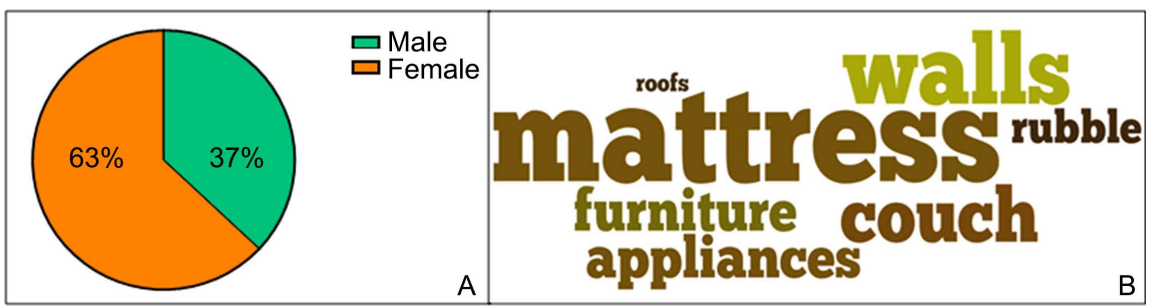

Figure 5. Gender frequency of participant public (A) in a typical health promotion event using the Interactive House device in countryside towns in Brazil. Word Cloud showing the most frequently used terms in the replies of the interviewed participants entering the Interactive House, indicating main kissing-bug (triatomines) hiding spots (B). 


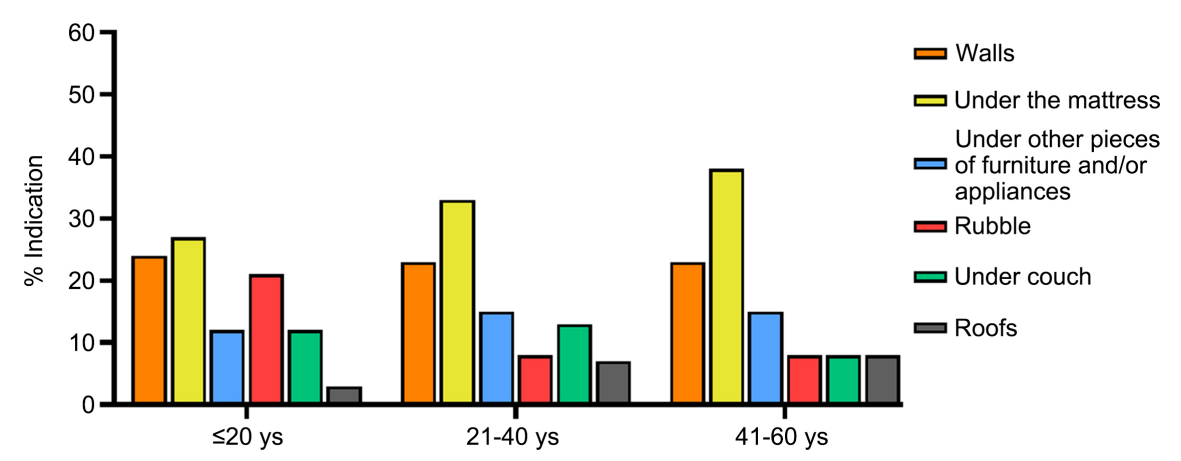

Figure 6. Distribution of different triatomines hiding spots indicated by participants, according to age groups among Interactive House visitors.

[24], the domestic dogs may harbor protozoal parasites such as Toxoplasma gondii, Babesia sp. and Giardia lamblia [83]. Thus, our deservedly called "friends" may hide dangerous "dwellers" inside and outside our residences and both vectors and reservoirs may be found in both intradomiciliary and peridomiciliary sites [18]. Interestingly the dog infection may be promoted by the richness of other peridomiciliary domestic animal species [83]. Therefore, the presence of chicken coops in the house proximity is considered a risk factor. For these reasons, intradomiciliary and peridomiciliary cleaning and organization can comprise a valuable tool in Leishmaniasis [36] [84] and Chagas disease [85] [86] control programs, participating in integrated vector management. It is noteworthy that community participation was shown to be effective in sustained control of triatomine house infestation [87] [89]. Surprisingly, although the bedroom and Livingroom infestations are the most frequent (90 Dias et al. 2016), bed mattresses and couches were not pointed as triatomine hiding places by most of the House visitors. This may indicate that even in endemic areas the population may be unaware of the insect habits during household colonization. Thus, education for health remains required for effective control.

Education interventions for health promotion empowering the population to control vector breeding sites are relevant since insecticide resistance are becoming more frequent among, triatomines [91] [92] [93], phlebotomines [94] [95], Aedes [96] [97], Anopheles [98] [99] etc. In such educative interventions, protozoal, bacterial and helminthic pathogens may be approached using biscuit resin-made models [100].

SARS/CoV-2 can be found in sewers, being released in fecal waste, leading to dissemination to several areas of the city, which can cause fecal-oral transmission [101] [102] in a similar way as the transmission of intestinal parasitic infections [103]. Therefore, similar or identical preventive measures such as frequent hand washing, as well as adequate food hygiene, care with drinking water, among others can be endorsed through education/communication interventions [77]-[100]. Thus, there is a need to involve the general public in preventive activities in COVID-19 and other infections, controlling the pandemic, which may also constitute comorbidities, as well as in future epidemics. For this reason, educational 
interventions for health promotion disseminating prophylactic measures of different viruses, as well as other endemic diseases are of great relevance [104]. In this regard it is noteworthy that the discontinued surveillance, larval control activity during lockdown was shown to lead to enhanced Aedes larval indices in two localities in India [105] and the COVID-19 pandemic may be associated with outbreaks of bites of insects such as Simulium tuberosum [106], an onchocerciasis vector. In addition, pet ectoparasites such as cat fleas [107] may take part in the COVID-19 spread.

Thus, population empowerment via education and engagement may be useful in control measures towards different infections. Interestingly, maternal education level was shown to be inversely related to childhood mortality [78] [79]. The tool presented here may empower and engage communities to fight diseases disseminated in the domiciliary/peri-domiciliary milieu.

\section{Conclusion}

Taken together the present observations allow the conclusion that it is possible to use low-cost material to create a ludic interactive health promotion device approaching different infectious and parasitic diseases as well as poisonous animals, suitable for the general public, including different ages and socioeconomic levels as well as community health agents. The present interactive dynamic activity can presumably encourage discussions on disease prevention via engagement and encouragement of students and community to search, discover and surveil health threats in the neighborhood becoming empowered to play active roles in their public health.

\section{Acknowledgements}

We thank the great researcher Virginia Schall (in memoriam) for the example of dedication and motivation to carry out health promotion in a ludic and consequently effective way. All the eventual collaborators of the Science on the Road programme at Fiocruz are acknowledged. This work was sponsored by $\mathrm{CNPq}$, INOVA/Fiocruz and Capes. MAVS is a CNPq Research fellow.

\section{Conflicts of Interest}

The authors declare no conflicts of interest regarding the publication of this paper.

\section{References}

[1] Hotez, P.J. (2013) Forgotten People, Forgotten Diseases: The Neglected Tropical Diseases and Their Impact on Global Health and Development. 2nd Edition, American Society for Microbiology Press, USA.

https://doi.org/10.1128/9781555818753

[2] Samuelson, H., Baniassadi, A., Lin, A., Izaga González, P., Brawley, T. and Narula, T. (2020) Housing as a Critical Determinant of Heat Vulnerability and Health. Science of the Total Environment, 720, Article ID: 137296. 
https://doi.org/10.1016/j.scitotenv.2020.137296

[3] WHO (2018) Household Air Pollution and Health. https://www.who.int/en/news-room/fact-sheets/detail/household-air-pollution-and -health

[4] Zhou, Q., Zhang, X., Chen, J. and Zhang, Y. (2020) Do Double-Edged Swords Cut Both Ways? Housing Inequality and Haze Pollution in Chinese Cities. Science of the Total Environment, 719, Article ID: 137404. https://doi.org/10.1016/j.scitotenv.2020.137404

[5] Anastasiou, E., Feinberg, A., Tovar, A., Gill, E., Ruzmyn Vilcassim, M.J., Wyka, K., et al. (2020) Secondhand Smoke Exposure in Public and Private High-Rise Multiunit Housing Serving Low-Income Residents in New York City Prior to Federal Smoking Ban in Public Housing, 2018. Science of the Total Environment, 704, Article ID: 135322. https://doi.org/10.1016/j.scitotenv.2019.135322

[6] Poowuttikul, P., Saini, S. and Seth, D. (2019) Inner-City Asthma in Children. Clinical Reviews in Allergy \& Immunology, 56, 248-268.

https://doi.org/10.1007/s12016-019-08728-x

[7] Carmichael, L., Prestwood, E., Marsh, R., Ige, J., Williams, B., Pilkington, P., et al. (2020) Healthy Buildings for a Healthy City: Is the Public Health Evidence Base Informing Current Building Policies? Science of the Total Environment, 719, Article ID: 137146. https://doi.org/10.1016/j.scitotenv.2020.137146

[8] Mayans, L. (2019) Lead Poisoning in Children. American Family Physician, 100, 24-30.

[9] de Haro, L. and Pommier, P. (2003) Envenomation: A Real Risk of Keeping Exotic House Pets. Veterinary and Human Toxicology, 45, 214-216.

[10] Erickson, T.B. and Cheema, N. (2017) Arthropod Envenomation in North America. Emergency Medicine Clinics of North America, 35, 355-375.

https://doi.org/10.1016/j.emc.2017.01.001

[11] Overgaauw, P.A.M., Vinke, C.M., Van Hagen, M.A.E. and Lipman, L.J.A. (2020) A One Health Perspective on the Human-Companion Animal Relationship with Emphasis on Zoonotic Aspects. International Journal of Environmental Research and Public Health, 17, 3789. http://www.mdpi.com/journal/ijerph https://doi.org/10.3390/ijerph17113789

[12] Qian, H., Miao, T., Liu, L., Zheng, X., Luo, D. and Li, Y. (2020) Indoor Transmission of SARS-CoV-2. Indoor Air. https://www.medrxiv.org/content/10.1101/2020.04.04.20053058v1

[13] Mott, K.E., Desjeux, P., Moncayo, A., Ranque, P. and De Raadt, P. (1990) Parasitic Diseases and Urban Development. Bulletin of the World Health Organization, 68, 691-698.

[14] Barbosa-Silva, A.N., Da Câmara, A.C.J., Martins, K., Nunes, D.F., de Oliveira, P.I.C., de Azevedo, P.M., et al. (2016) Characteristics of Triatomine Infestation and Natural Trypanosoma cruzi Infection in the State of Rio Grande do Norte, Brazil. Revista da Sociedade Brasileira de Medicina Tropical, 49, 57-67. https://doi.org/10.1590/0037-8682-0300-2015

[15] Da Silveira, E.A., Ribeiro, I.S., Amorim, M.S., Rocha, D.V., Coutinho, H.S., de Freitas, L.M., et al. (2016) Correlation between Infection Rate of Triatominies and Chagas Disease in Southwest of Bahia, Brazil: A Warning Sign? The Anais da Academia Brasileira de Ciências, 88, 1941-1951. https://doi.org/10.1590/0001-3765201620150744

[16] Fidalgo, A., Da Costa, A.C., Da Silva Filho, J.D., Da Silva Cândido, D., Freitas, E.C., 
Pereira, L.D.S., et al. (2018) Insect Vectors of Chagas Disease (Trypanosoma cruzi) in Northeastern Brazil. Revista da Sociedade Brasileira de Medicina Tropical, 51, 174-182. https://doi.org/10.1590/0037-8682-0408-2017

[17] Mendonça, V.J., De Oliveira, J., Rimoldi, A., Filho, J.C.R.F., De Araújo, R.F. and Da Rosa, J.A. (2015) Triatominae Survey (Hemiptera: Reduviidae: Triatominae) in the South-Central Region of the State of Bahia, Brazil between 2008 and 2013. The American Society of Tropical Medicine and Hygiene, 92, 1076-1080. https://doi.org/10.4269/ajtmh.14-0556

[18] Reyes, M., Torres, Á., Esteban, L., Flórez, M. and Angulo, V.M. (2017) Riesgo de transmisión de la enfermedad de Chagas por intrusión de triatominos y mamíferos silvestres en Bucaramanga, Santander, Colombia. Biomedica, 37, 68-78. https://doi.org/10.7705/biomedica.v37i1.3051

[19] Vannier-Santos, M., Martiny, A. and Souza, W. (2002) Cell Biology of Leishmania spp.: Invading and Evading. Current Pharmaceutical Design, 8, 297-318. https://doi.org/10.2174/1381612023396230

[20] Ballart, C., Vidal, G., Picado, A., Cortez, M.R., Torrico, F., Torrico, M.C., et al. (2016) Intradomiciliary and Peridomiciliary Captures of Sand Flies (Diptera: Psychodidae) in the Leishmaniasis Endemic Area of Chapare Province, Tropic of Cochabamba, Bolivia. Acta Tropica, 154, 121-124.

https://doi.org/10.1016/j.actatropica.2015.11.007

[21] Guimarães-E-Silva, A.S., De Oliveira Silva, S., Da Silva, R.C.R., Pinheir, V.C.S., Rebêlo, J.M.M. and Melo, M.N. (2017) Leishmania Infection and Blood Food Sources of Phlebotomines in an Area of Brazil Endemic for Visceral and Tegumentary Leishmaniasis. PLoS ONE, 12, e0179052.

https://doi.org/10.1371/journal.pone.0179052

[22] Pereira-Filho, A., Fonteles, R.S., Da Conceição Abreu Bandeira, M., Moraes, J.L.P., Rebêlo, J.M.M. and Melo, M.N. (2018) Molecular Identification of Leishmania spp. in Sand Flies (Diptera: Psychodidae: Phlebotominae) in the Lençóis Maranhenses National Park, Brazil. Journal of Medical Entomology, 55, 989-994. https://doi.org/10.1093/jme/tjy014

[23] Vexenat, J.A., Barreto, A.C., Cuba, C.A.C. and Marsden, P.D. (1986) Características epidemiológicas da leishmaniose tegumentar americana em uma região endêmica do Estado da Bahia: III. Fauna flebotomínica. Memórias do Instituto Oswaldo Cruz, 81, 293-301. https://doi.org/10.1590/S0074-02761986000300005

[24] Travi, B.L. (2019) Considering Dogs as Complementary Targets of Chagas Disease Control. Vector-Borne and Zoonotic Diseases, 19, 90-94. https://doi.org/10.1089/vbz.2018.2325

[25] Vexenat, J.A., Castro, J.A.F., Cavalcante, R., Tavares, J.P., Silva, M.R.B., Batista, W.H., et al. (1994) Visceral Leishmaniasis in Teresina, State of Piauí, Brazil: Preliminary Observations on the Detection and Transmissibility of Canine and Sandfly Infections. Memórias do Instituto Oswaldo Cruz, 89, 131-135. https://doi.org/10.1590/S0074-02761994000200001

[26] Curtis-Robles, R., Snowden, K.F., Dominguez, B., Dinges, L., Rodgers, S., Mays, G., et al. (2017) Epidemiology and Molecular Typing of Trypanosoma cruzi in Naturally-Infected Hound Dogs and Associated Triatomine Vectors in Texas, USA. PLOS Neglected Tropical Diseases, 11, e0005298. https://doi.org/10.1371/journal.pntd.0005298

[27] Asfaram, S., Fakhar, M. and Teshnizi, S.H. (2019) Is the Cat an Important Reservoir Host for Visceral Leishmaniasis? A Systematic Review with Meta-Analysis. Journal of Venomous Animals and Toxins including Tropical Diseases, 25, e20190012. 
https://doi.org/10.1590/1678-9199-jvatitd-2019-0012

[28] Truppel, J.H., Otomura, F., Teodoro, U., Massafera, R., Da Costa-Ribeiro, M.C.V., Catarino, C.M., et al. (2014) Can Equids Be a Reservoir of Leishmania braziliensis in Endemic Areas? PLoS ONE, 9, e93731.

https://doi.org/10.1371/journal.pone.0093731

[29] Roque, A.L.R. and Jansen, A.M. (2014) Wild and Synanthropic Reservoirs of Leishmania Species in the Americas. International Journal for Parasitology: Parasites and Wildlife, 3, 251-262. https://doi.org/10.1016/j.ijppaw.2014.08.004

[30] Zecca, I.B., Hodo, C.L., Slack, S., Auckland, L., Rodgers, S., Killets, K., et al. (2020) Prevalence of Trypanosoma cruzi Infection and Associated Histologic Findings in Domestic Cats (Felis catus). Veterinary Parasitology, 278, Article ID: 109014. https://doi.org/10.1016/j.vetpar.2019.109014

[31] Gunter, S.M., Brown, E.L., Gorchakov, R., Murray, K.O. and Garcia, M.N. (2017) Sylvatic Transmission of Trypanosoma cruzi among Domestic and Wildlife Reservoirs in Texas, USA: A Review of the Historical Literature. Zoonoses and Public Health, 64, 313-327. https://doi.org/10.1111/zph.12330

[32] Gottdenker, N.L., Chaves, L.F., Calzada, J.E., Saldaña, A. and Carroll, C.R. (2012) Host Life History Strategy, Species Diversity, and Habitat Influence Trypanosoma cruzi Vector Infection in Changing Landscapes. PLOS Neglected Tropical Diseases, 6, 5-7. https://doi.org/10.1371/journal.pntd.0001884

[33] Levy, M.Z., Tustin, A., Castillo-Neyra, R., Mabud, T.S., Levy, K., Barbu, C.M., et al. (2015) Bottlenecks in Domestic Animal Populations Can Facilitate the Emergence of Trypanosoma cruzi, the Aetiological Agent of Chagas Disease. Proceedings of the Royal Society B: Biological Sciences, 282, Article ID: 20142807. https://doi.org/10.1098/rspb.2014.2807

[34] Hernández-Cortazar, I., Guardia, K.A., Torres-Castro, M., Acosta-Viana, K., Guzmán-Marin, E., Chan-Pérez, J.I., et al. (2018) Frequency of Trypanosoma cruzi Infection in Synanthropic and Wild Rodents Captured in a Rural Community in Southeast of Mexico. Veterinary Medicine International, 2018, Article ID: 8059613. https://doi.org/10.1155/2018/8059613

[35] Rosal, G.G., Nogueda-Torres, B., Villagrán, M.E., de Diego-Cabrera, J.A., MontañezValdez, O.D. and Martínez-Ibarra, J.A. (2018) Chagas Disease: Importance of Rats as Reservoir Hosts of Trypanosoma cruzi (Chagas, 1909) in Western Mexico. Journal of Infection and Public Health, 11, 230-233. https://doi.org/10.1016/j.jiph.2017.07.017

[36] Legriffon, C.M., Reinhold-Castro, K.R., Fenelon, V.C., Neitzke-Abreu, H.C. and Teodoro, U. (2012) Frequência de flebotomíneos em ambiente rural com boas condições de limpeza e organização, no Estado do Paraná, Brasil. Revista da Sociedade Brasileira de Medicina Tropical, 45, 77-82.

https://doi.org/10.1590/S0037-86822012000100015

[37] Teodoro, U., Santos, D.R., Santos, A.R., Oliveira, O., Poiani, L.P., Kühl, J.B., et al. (2007) Avaliação de medidas de controle de flebotomíneos no norte do Estado do Paraná, Brasil. Cadernos de Saúde Pública, 23, 2597-2604.

https://doi.org/10.1590/S0102-311X2007001100007

[38] Rojas-de-Arias, A. (2001) Chagas Disease Prevention through Improved Housing Using an Ecosystem Approach to Health Prevención de la enfermedad de Chagas vía mejoramiento de la vivienda com un enfoque ecosistémico de la salud. Vol. 17. https://doi.org/10.1590/S0102-311X2001000700017

[39] Bonfante-Cabarcas, R., Rodríguez-Bonfante, C., Vielma, B., García, D., Saldivia, 
A.M., Aldana, E., et al. (2011) Seroprevalencia de la infección por Trypanosoma cruzi y factores asociados en un área endémica de Venezuela. Cadernos de Saúde Pública, 27, 1917-1929. https://doi.org/10.1590/S0102-311X2011001000005

[40] Feliciangeli, M.D., Sánchez-Martín, M.J., Suárez, B., Marrero, R., Torrellas, A., Bravo, A., et al. (2007) Risk Factors for Trypanosoma cruzi Human Infection in Barinas State, Venezuela. http://www.who.int/tdr https://doi.org/10.4269/ajtmh.2007.76.915

[41] Medina-Torres, I., Vázquez-Chagoyán, J.C., Rodríguez-Vivas, R.I. and De OcaJiménez, R.M. (2010) Risk Factors Associated with Triatomines and Its Infection with Trypanosoma cruzi in Rural Communities from the Southern Region of the State of Mexico, Mexico. The American Society of Tropical Medicine and Hygiene, 82, 49-54. https://doi.org/10.4269/ajtmh.2010.08-0624

[42] Méndez, N., Baeza-Herrera, L., Ojeda-Baranda, R., Huchim-Lara, O. and GómezCarro, S. (2017) Perfil clinicoepidemiológico de la infección por Chikungunya en casos hospitalarios atendidos en 2015 en Mérida, México. Revista Panamericana de Salud Pública, 41, 1-5. https://doi.org/10.26633/RPSP.2017.91

[43] Gibson, G., Souza-Santos, R., Honório, N.A., Pacheco, A.G., Moraes, M.O., Kubelka, C., et al. (2014) Conditions of the Household and Peridomicile and Severe Dengue: A Case-Control Study in Brazil. Infection Ecology \& Epidemiology, 4, 1-7. https://doi.org/10.3402/iee.v4.22110

[44] Maloy, S. and Atlas, R.M. (2014) One Health: People, Animals, and the Environment. Press A, Editor.

[45] Zinsstag, J., Waltner-Toews, D. and Tanner, M. (2015) Theoretical Issues of One Health. In: Zinsstag, J., Schelling, E., Waltner-Toews, D., Whittaker, M. and Tanner, M., Eds., One Health: The Theory and Practice of Integrated Health Approaches, CABI, Wallingford, 16-25. https://doi.org/10.1079/9781780643410.0016

[46] Dantas-Torres, F., Miró, G., Baneth, G., Bourdeau, P., Breitschwerdt, E., Capelli, G., et al. (2019) Canine Leishmaniasis Control in the Context of One Health. Emerging Infectious Diseases, 25, 1-4. https://doi.org/10.3201/eid2512.190164

[47] Garcia, M.N., O’Day, S., Fisher-Hoch, S., Gorchakov, R., Patino, R., Feria Arroyo, T.P., et al. (2016) One Health Interactions of Chagas Disease Vectors, Canid Hosts, and Human Residents along the Texas-Mexico Border. PLOS Neglected Tropical Diseases, 10, e0005074. https://doi.org/10.1371/journal.pntd.0005074

[48] Scott, J. (2020) Proposed Integrated Control of Zoonotic Plasmodium knowlesi in Southeast Asia Using Themes of One Health. Tropical Medicine and Infectious Disease, 5, 175. https://doi.org/10.3390/tropicalmed5040175

[49] Heymann, D.L. and Dixon, M. (2014) The Value of the One Health Approach: Shifting from Emergency Response to Prevention of Zoonotic Disease Threats at Their Source. In: Atlas, R.M. and Maloy, S., Eds., One Health: People, Animals, and the Environment, John Wiley \& Sons, Inc., Hoboken, 17-31. https://doi.org/10.1128/9781555818432.ch2

[50] Benelli, G. and Duggan, M.F. (2018) Management of Arthropod Vector Data- Social and Ecological Dynamics Facing the One Health Perspective. Acta Tropica, 182, 80-91. https://doi.org/10.1016/j.actatropica.2018.02.015

[51] Schall, V.T., Barros, H.S., Jardim, J.B., Secundino, N.F.C. and Pimenta, P.F.P. (2009) Prevenção domiciliar da dengue: Avaliação preliminar de tela protetora para pratos de vasos de planta. Revista de Saúde Pública, 43, 895-902. http://www.sus20anos https://doi.org/10.1590/S0034-89102009000500022

[52] Dunn, R.R. (2018) Never Home Alone: From Microbes to Millipedes, Camel Crick- 
ets, and Honeybees, the Natural History of Where We Live. Basic Books, New York, $278 \mathrm{p}$.

[53] Cordeiro da Silva, P., Mesaque Martins, A. and Torres Schall, V. (2013) Cooperação entre agentes de endemias e escolas na identificação e controle da dengue TT. Cooperation between Health Personnel and Schools for the Identification and Control of Dengue TT. Cooperación entre agentes de endemias y escuelas en la identific. Revista Brasileira em Promoção da Saúde, 26, 397-404.

http://www.unifor.br/images/pdfs/rbps/2013.3 artigo13.pdf https://doi.org/10.5020/18061230.2013.p404

[54] Beatson, S.H. (1972) Pharaoh's Ants as Pathogen Vectors in Hospitals. The Lancet, 299, 425-427. https://doi.org/10.1016/S0140-6736(72)90869-0

[55] Strand, M.A. and Brooks, M.A. (1977) Pathogens of Blattidae (Cockroaches). Bulletin of the World Health Organization, 55, 289-296.

[56] Fakoorziba, M.R., Eghbal, F., Hassanzadeh, J. and Moemenbellah-Fard, M.D. (2010) Cockroaches (Periplaneta americana and Blattella germanica) as Potential Vectors of the Pathogenic Bacteria Found in Nosocomial Infections. Annals of Tropical Medicine \& Parasitology, 104, 521-528. https://doi.org/10.1179/136485910X12786389891326

[57] Memona, H., Manzoor, F. and Anjum, A.A. (2016) Cockroaches (Blattodea: Blattidae): A Reservoir of Pathogenic Microbes in Human-Dwelling Localities in Lahore. Journal of Medical Entomology, 54, 435-440. https://doi.org/10.1093/jme/tjw168

[58] Khamesipour, F., Lankarani, K.B., Honarvar, B. and Kwenti, T.E. (2018) A Systematic Review of Human Pathogens Carried by the Housefly (Musca domestica L.). BMC Public Health, 18, Article No. 1049. https://doi.org/10.1186/s12889-018-5934-3

[59] Šrámová, H., Daniel, M., Absolonová, V., Dědičová, D., Jedlicková, Z., Lhotová, H., et al. (1992) Epidemiological Role of Arthropods Detectable in Health Facilities. Journal of Hospital Infection, 20, 281-292. https://doi.org/10.1016/0195-6701(92)90006-8

[60] Tilahun, B., Worku, B., Tachbele, E., Terefe, S., Kloos, H. and Legesse, W. (2012) High Load of Multi-Drug Resistant Nosocomial Neonatal Pathogens Carried by Cockroaches in a Neonatal Intensive Care Unit at Tikur Anbessa Specialized Hospital, Addis Ababa, Ethiopia. Antimicrobial Resistance \& Infection Control, 1, 1-7. https://doi.org/10.1186/2047-2994-1-12

[61] Alves, T.S., Lara, G.H.B., Maluta, R.P., Ribeiro, M.G. and Leite, D.S. (2018) Carrier Flies of Multidrug-Resistant Escherichia coli as Potential Dissemination Agent in Dairy Farm Environment. Science of the Total Environment, 633, 1345-1351.

https://doi.org/10.1016/j.scitotenv.2018.03.304

[62] Onwugamba, F.C., Fitzgerald, J.R., Rochon, K., Guardabassi, L., Alabi, A., Kühne, S., et al. (2018) The Role of "Filth Flies" in the Spread of Antimicrobial Resistance. Travel Medicine and Infectious Disease, 22, 8-17. https://doi.org/10.1016/j.tmaid.2018.02.007

[63] Hyde, J., Gorham, C., Brackney, D.E. and Steven, B. (2019) Antibiotic Resistant Bacteria and Commensal Fungi Are Common and Conserved in the Mosquito $\mathrm{Mi}$ crobiome. PLoS ONE, 14, e0218907. https://doi.org/10.1101/670802

[64] Chadee, D. and Le Maitre, A. (1990) Ants: Potential Mechanical Vectors of Hospital Infections in Trinidad. Transactions of the Royal Society of Tropical Medicine and Hygiene, 84, 297. https://doi.org/10.1016/0035-9203(90)90294-O 
[65] Máximo, H.J., Felizatti, H.L., Ceccato, M., Cintra-Socolowski, P. and Beretta, A.L.R.Z. (2014) Ants as Vectors of Pathogenic Microorganisms in a Hospital in São Paulo County, Brazil. BMC Research Notes, 7, Article No. 554. https://doi.org/10.1186/1756-0500-7-554

[66] Simothy, L., Mahomoodally, F. and Neetoo, H. (2018) A Study on the Potential of Ants to Act as Vectors of Foodborne Pathogens. AIMS Microbiology, 4, 319-333. https://doi.org/10.3934/microbiol.2018.2.319

[67] Moreira, D.D.O., de Morais, V., Vieira-da-Motta, O., Campos-Farinha, A.E.C. and Tonhasca, A. (2005) Formigas como agentes carreadores de bactérias resistentes em hospitais. Neotropical Entomology, 34, 999-1006. https://doi.org/10.1590/S1519-566X2005000600017

[68] Rodovalho, C.M., Santos, A.L., Marcolino, M.T., Bonetti, A.M. and Brandeburgo, M.A.M. (2007) Urban Ants and Transportation of Nosocomial Bacteria. Neotropical Entomology, 36, 454-458. https://doi.org/10.1590/S1519-566X2007000300014

[69] Aquino, R.S.S., Silveira, S.S., Pessoa, W.F.B., Rodrigues, A., Andrioli, J.L., Delabie, J.H.C., et al. (2013) Filamentous Fungi Vectored by Ants (Hymenoptera: Formicidae) in a Public Hospital in North-Eastern Brazil. Journal of Hospital Infection, 83, 200-204. https://doi.org/10.1016/j.jhin.2012.11.022

[70] Escandón-Vargas, K., Osorio, L. and Astudillo-Hernández, M. (2017) Seroprevalence and Factors Associated with Leptospira Infection in an Urban District of Cali, Colombia. Cadernos de Saúde Pública, 33, e00039216. https://doi.org/10.1590/0102-311x00039216

[71] Warrell, D.A. (2019) Venomous Bites, Stings, and Poisoning: An Update. Infectious Disease Clinics of North America, 33, 17-38. https://doi.org/10.1016/j.idc.2018.10.001

[72] Torrez, P.P.Q., Dourado, F.S., Bertani, R., Cupo, P. and França, F.O.S. (2019) Scorpionism in Brazil: Exponential Growth of Accidents and Deaths from Scorpion Stings. Revista da Sociedade Brasileira de Medicina Tropical, 52, e20180350. http://abracit.org.br/wp/centros https://doi.org/10.1590/0037-8682-0350-2018

[73] Phillips, D. (2018) Scorpion Deaths on Rise in Brazil as Arachnid Adapts to Urban Life.

https://www.theguardian.com/world/2018/jul/15/scorpion-deaths-rise-brazil-citiesurban-adaptation-risks

[74] Cruz, E.F.S., Yassuda, C.R.W., Jim, J. and Barraviera, B. (1995) Programa de controle de surto de escorpião Tityus serrulatus, Lutz e Mello 1922, no município de Aparecida, SP (Scorpiones, Buthidae). Revista da Sociedade Brasileira de Medicina Tropical, 28, 123-128. https://doi.org/10.1590/S0037-86821995000200007

[75] Pole, C.J. (2004) Seeing Is Believing? Approaches to Visual Research. Elsevier Ltd., Amsterdam. https://doi.org/10.1016/S1042-3192(2004)7

[76] Rose, G. (2013) Visual Methodologies-An Introduction to the Interpretation of Visual Materials. SAGE Publications, London.

[77] Suarez-Fontes, A.M., Vieira, A.D., Raya, B., Melo, A.P., Gonçalves, G., Albergaria, I., et al. (2014) Handwashing for Health: A Focusing Focus. In: Méndez-Vilas, A., Ed., Microscopy: Advances in Scientific Research and Education, Formatex Research Center, Badajoz, Vol. 2, 1157-1161.

[78] Caldwell, J.C. (1979) Education as a Factor in Mortality Decline: An Examination of 
Nigerian Data. Population Studies (NY), 33, 395-413. https://doi.org/10.2307/2173888

[79] Caldwell, J. and McDonald, P. (1982) Influence of Maternal Education on Infant and Child Mortality: Levels and Causes. Health Policy Education, 2, 251-267.

https://doi.org/10.1016/0165-2281(82)90012-1

[80] da Silva, J.B., Piva, C., Falavigna-Guilherme, A.L., Rossoni, D.F. and de Ornelas Toledo, M.J. (2016) Spatial Distribution and Enteroparasite Contamination in Peridomiciliar Soil and Water in the Apucaraninha Indigenous Land, Southern Brazil. Environmental Monitoring and Assessment, 188, 217. https://doi.org/10.1007/s10661-016-5216-4

[81] Araújo-Neto, V.T., Honorato, N.R.M., de Oliveira Santana, R., Barbosa-Silva, A.N., da Matta Guedes, P.M., Chiari, E., et al. (2019) Trypanosoma cruzi Circulating among Dogs and Triatomines in the Endemic Countryside of the State of Rio Grande do Norte, Brazil. Acta Tropica, 200, Article ID: 105067.

https://doi.org/10.1016/j.actatropica.2019.105067

[82] Vianna, E.N., Morais, M.H.F., de Almeida, A.S., Sabroza, P.C., Reis, I.A., Dias, E.S., et al. (2016) Abundance of Lutzomyia Longipalpis in Urban Households as Risk Factor of Transmission of Visceral Leishmaniasis. Memórias do Instituto Oswaldo Cruz, 111, 302-310. https://doi.org/10.1590/0074-02760150366

[83] Esch, K.J. and Petersen, C.A. (2013) Transmission and Epidemiology of Zoonotic Protozoal Diseases of Companion Animals. Clinical Microbiology Reviews, 26, 58-85. https://doi.org/10.1128/CMR.00067-12

[84] Saldaña, A., Calzada, J.E., Pineda, V., Perea, M., Rigg, C., González, K., et al. (2015) Risk Factors Associated with Trypanosoma cruzi Exposure in Domestic Dogs from a Rural Community in Panama. Memórias do Instituto Oswaldo Cruz, 110, 936944. https://doi.org/10.1590/0074-02760150284

[85] Teodoro, U., Rodrigues dos Santos, D., Rodrigues dos Santos, A., de Oliveira, O., Silvestre dos Santos, E., Coeto Neitzke, H., et al. (2006) Evaluation of Sandfly Control in Lobato Municipality, Paraná State, Southern Brazil. Cadernos de Saúde Pública, 22, 451-455. https://doi.org/10.1590/S0102-311X2006000200022

[86] Ferral, J., Chavez-Nuñez, L., Euan-Garcia, M., Ramirez-Sierra, M.J., NajeraVazquez, M.R. and Dumonteil, E. (2010) Comparative Field Trial of Alternative Vector Control Strategies for Non-Domiciliated Triatoma dimidiata. The American Society of Tropical Medicine and Hygiene, 82, 60-66.

https://doi.org/10.4269/ajtmh.2010.09-0380

[87] Lardeux, F., Depickère, S., Aliaga, C., Chavez, T. and Zambrana, L. (2015) Experimental Control of Triatomainfestans in Poor Rural Villages of Bolivia through Community Participation. Transactions of the Royal Society of Tropical Medicine and Hygiene, 109, 150-158. https://doi.org/10.1093/trstmh/tru205

[88] Bryan, R.T., Balderrama, F., Tonn, R.J. and Dias, J.C. (1994) Community Participation in Vector Control: Lessons from Chagas' Disease. The American Society of Tropical Medicine and Hygiene, 50, 61-71.

https://doi.org/10.4269/ajtmh.1994.50.61

[89] Gürtler, R.E. and Yadon, Z.E. (2015) Eco-Bio-Social Research on Community-Based Approaches for Chagas Disease Vector Control in Latin America. Transactions of the Royal Society of Tropical Medicine and Hygiene, 109, 91-98. https://doi.org/10.1093/trstmh/tru203

[90] Dias, J.V., Queiroz, D.R., Martins, H.R., Gorla, D.E., Pires, H.H. and Diotaiuti, L. (2016) Spatial Distribution of Triatomines in Domiciles of an Urban Area of the 
Brazilian Southeast Region. Memórias do Instituto Oswaldo Cruz, 111, 43-50. https://doi.org/10.1590/0074-02760150352

[91] Barbu, C., Dumonteil, E. and Gourbière, S. (2011) Evaluation of Spatially Targeted Strategies to Control Non-Domiciliated Triatoma dimidiata Vector of Chagas Disease. PLOS Neglected Tropical Diseases, 5, e1045.

https://doi.org/10.1371/journal.pntd.0001045

[92] Mougabure-Cueto, G. and Picollo, M.I. (2015) Insecticide Resistance in Vector Chagas Disease: Evolution, Mechanisms and Management. Acta Tropica, 149, 7085. https://doi.org/10.1016/j.actatropica.2015.05.014

[93] Pessoa, G.C.D., Vinãs, P.A., Rosa, A.C.L. and Diotaiuti, L. (2015) History of Insecticide Resistance of Triatominae Vectors. Revista da Sociedade Brasileira de Medicina Tropical, 48, 380-389. https://doi.org/10.1590/0037-8682-0081-2015

[94] Dhiman, R.C. and Yadav, R.S. (2016) Insecticide Resistance in Phlebotomine Sandflies in Southeast Asia with Emphasis on the Indian Subcontinent. Infectious Diseases of Poverty, 5, 1-10. https://doi.org/10.1186/s40249-016-0200-3

[95] Çetin, H. and Özbel, Y. (2017) Sand Flies and Their Control Methods. Türkiye Parazitoloji Dergisi, 41, 102-113. https://doi.org/10.5152/tpd.2017.5296

[96] Francis, S., Saavedra-Rodriguez, K., Perera, R., Paine, M., Black, W.C. and Delgoda, R. (2017) Correction: Insecticide Resistance to Permethrin and Malathion and Associated Mechanisms in Aedes aegypti Mosquitoes from St. Andrew Jamaica. PLoS ONE, 12, e0184387. https://doi.org/10.1371/journal.pone.0184387

[97] Moyes, C.L., Vontas, J., Martins, A.J., Ng, L.C., Koou, S.Y., Dusfour, I., et al. (2017) Contemporary Status of Insecticide Resistance in the Major Aedes Vectors of Arboviruses Infecting Humans. PLOS Neglected Tropical Diseases, 11, e0005625. https://doi.org/10.1371/journal.pntd.0005625

[98] Riveron, J.M., Chiumia, M., Menze, B.D., Barnes, K.G., Irving, H., Ibrahim, S.S., et al. (2015) Rise of Multiple Insecticide Resistance in Anopheles funestus in Malawi: A Major Concern for Malaria Vector Control. Malaria Journal, 14, 344. https://doi.org/10.1186/s12936-015-0877-y

[99] Rubert, A., Chandenier, J. and Desoubeaux, G. (2016) Résistance aux insecticides chez le moustique anophèle: Des obstacles en plus dans la lutte antipaludique Insecticide resistance in Anopheles mosquitoes: Additional obstacles in the battle against malaria. Médecine et Santé Tropicales, 26, 423-431.

https://doi.org/10.1684/mst.2016.0634

[100] Suarez-Fontes, A.M., Araujo, S., Suarez Fontes, S. and Vannier-Santos, M. (2018) Health Promotion through Scientific Literacy: The Experience of the "Science on the Road" Program. ReonFacema, 4, 929-940.

[101] Heller, L., Mota, C.R. and Greco, D.B. (2020) COVID-19 Faecal-Oral Transmission: Are We Asking the Right Questions? Science of the Total Environment, 729, Article ID: 138919. https://doi.org/10.1016/j.scitotenv.2020.138919

[102] Prado, T., Machado Fumian, T., Ferreira Mannarino, C., Gonçalves Maranhão, A., Mendonça Siqueira, M., Pereira Miagostovich, M., et al. (2020) Preliminary Results of SARS-CoV-2 Detection in Sewerage System in Niterói Municipality, Rio de Janeiro, Brazil. https://www.cdc https://doi.org/10.1590/0074-02760200196

[103] Suarez-Fontes, A.M., Fontes, S. and Vannier-Santos, M.A. (2017) Enteroparasitosis in Public Schools in Bahia: Parasitology Learning. Revista de Patologia Tropical, 46, 185. https://doi.org/10.5216/rpt.v46i2.47543

[104] Van den Broucke, S. (2020) Why Health Promotion Matters to the COVID-19 
Pandemic, and Vice Versa. Health Promotion International, 35, 181-186.

https://doi.org/10.1093/heapro/daaa042

[105] Daniel Reegan, A., Rajiv Gandhi, M., Cruz Asharaja, A., Devi, C. and Shanthakumar, S.P. (2020) COVID-19 Lockdown: Impact Assessment on Aedes Larval Indices, Breeding Habitats, Effects on Vector Control Programme and Prevention of Dengue Outbreaks. Heliyon, 6, e05181.

https://doi.org/10.1016/j.heliyon.2020.e05181

[106] Smith, A., Polcari, I., Maguiness, S. and Boull, C. (2020) An Outbreak of Acute Hemorrhagic Papules on the Posterior Neck in Children during the COVID-19 Pandemic. Pediatric Dermatology, 37, 1193-1194.

https://doi.org/10.1111/pde.14325

[107] Villar, M., Fernández De Mera, I.G., Artigas-Jerónimo, S., Contreras, M., Gortázar, C. and De La Fuente, J. (2020) Coronavirus in Cat Flea: Findings and Questions Regarding COVID-19. Parasites and Vectors, 3, Article No. 409.

https://doi.org/10.1186/s13071-020-04292-y 